\title{
Low cost design for measuring and assessing climatic indices for safe working environment
}

\author{
Awad M. Aljuaid \\ ${ }^{1}$ Industrial Engineering Department, College of Engineering, \\ Taif University, Taif, 888, Saudi Arabia.
}

\begin{abstract}
Employees performing different activities in industrial environment, with various clothing levels, various working conditions, and different climate variables including ambient air temperature, humidity, sun radiations level, different airflow velocities and patterns. It is very important to design a real time industrial environmental assessment tool, to assess comforts, risks and experienced disorder levels, based on measuring, monitoring and assessing the industrial environment climate indices. In the present work, a design of low-cost industrial environment assessment tool at various conditions is introduced. The system is designed to monitor the combined industrial environment, at different climate indices including; apparent temperature types (heat index, wind chill factor and wet-bulb globe temperature), discomfort index and temperature-humidity index. Based on indices' calculation results, fuzzy algorithm is used to assess the surrounding working state, setting notifications, on displays, to employees and supervisors at easy system.
\end{abstract}

Keywords: Industrial environment assessment, apparent temperature, ambient temperature, heat index, thermal comfort smart system, safety.

\section{INTRODUCTION}

Workers are frequently exposed to different environmental stresses, which may decrease occupational efficiency and may threaten lives. For decades companies and organizations are trying to develop their own systems and utilities and trying to setup and design their working environment in ways to increase the levels of comfort and productivity, and minimize potential of risks and hazards[1-3]. Physical exertion in a humid and hot working environment may lead to safety and productivity issues physical strain and occupational heat hazards such as rash, cramps and syncope[4]. Companies have been using several measuring environmental variables like ambient Temperature, Humidity, air flow (wind speed), solar radiation and exposure (stress and clothing). Apparent temperature can be defined as the temperature equivalent perceived by human's body and caused by the combined effects of ambient weather conditions like humidity, temperature, radiation, and wind speed[5]. The Weather Company's developed "FeelsLike" system, while other company such as AccuWeather's developed "RealFeel."[6]. The comfort heat (HI) index also called humiture; is a measure used to describe how hot ambient temperature similar to human's body feeling at a given humidity [7, 8]. The WBGT, is an apparent temperature type also called the heat stress index, it is a measure of how hot it feels-like for human body during working activities, when ambient temperature is combined with air humidity, visible, air flow and direct or radiant sunlight. It was started by military to a alert in several conditions related to heat accidents $[9,10]$. "Thermal comfort is defined as the condition of mind that expresses satisfaction with the thermal environment"[11]. It is a cognitive process integrated with psychological , physiological , and psychophysical aspects[12]. Discomfort index is a human physiological stress indicator based on thermal WBGT [13].

In the present work, a design of low-cost industrial environment assessment tool at various conditions and easy to present to employees and supervisors is introduced. The system is designed to monitor the combined environmental index, at different climate indices including; apparent temperature types (heat index, wind chill factor and wet-bulb globe temperature), discomfort index and temperaturehumidity index. Based on indices' calculation results, fuzzy algorithm is used to assess the surrounding working state, setting notifications, on displays, to employees and supervisors at easy and low-cost system. Section 2, provides system design methodology, working principle and algorithm. In section 3, The applied indices, definitions and limits are introduced. In section 4, System configuration, hardware building design and integration are discussed as well as, recommendations regarding subsystems and overall system Prototyping. Finally, recommendations and future work are discussed.

\section{METHODOLOGY AND WORKING PRINCIPLE WITH ALGORITHM}

The suggested design consists of main four subsystems; wireless sensors modules, base station unit main control unit and algorithm, wireless communication unit, data displaying and notification subsystems. The system is designed of the following tasks:

1) Specially designed sensor modules are placed in specific and various locations all over industrial workspace.

2) Data collection and transmission was accomplished applying the following:

a) Each of these sensor modules is developed with the next hardware group of sensors, control unit, wireless 
communication unit, power supply unit. Each sensor is selected for reading one basic environmental variable or factor in that specific location, mainly; ambient Temperature, Humidity, air flow (wind speed) and solar radiation.

b) Due to the large space in industrial locations, it is important to acquire data about the basic environmental variables and factors from various different and specific locations (sensors modules are placed in different locations in industrial space).

c) All the acquired data is sent wirelessly, from each and all sensor modules, to base station with the main control unit.

3) Data analysis was accomplished applying the following:

a) The base station, with control algorithm, calculates the average value of each of all environmental variables and factors. The average value is to be taken as the actual value of each specific variable and factor.

b) Using the average values, the base station calculates the values of climate indices including; apparent temperature types (heat index, wind chill factor and wet-bulb globe temperature), discomfort index and temperature-humidity index.

c) The designed system automatically and continuously monitors and assesses the industrial environment, in terms of interpreting the numerical values of climate indices to their effects experienced by human.

d) Based on calculations and assessments results, the system sets notifications to employees and supervisor on OEE displays, in addition, send data results to decision makers and enterprise's CEOs.

4) Notifications include the following data:

a) The values of all basic environmental variables and factors.

b) The values of all climatic indices (e.g. apparent temp. types)

c) Interpret the values of each calculated climatic index in terms of experienced levels of comfort, danger and effects experienced disorders.

d) Switch ON safety and health color code indicator.

5) Fuzzy algorithm is developed to assess the overall environmental state and conditions, the inputs to this algorithm are the environmental indices. While the output is single value that represents working conditions state in terms of four states: Comfortable, Acceptable with some disorders, Severe Discomfort and Extremely Dangerous.

6) Calibration methodology is to be applied to reduce error in calculations, such that the measuring tool is expresses the actual values of all variables and climate indices.

7) The suggested design can be developed to have the form of one device that can be fixed on a wall, to read, calculate, and display the direct environmental indices in any given location.

\section{THE APPLIED INDICES IN THE TOOL DESIGN}

The direct indices, that are to be applied to analyze and assess, the environmental and climatic working conditions are: the apparent temperature, the thermal comfort, the discomfort index and the temperature-humidity index.

In this section, for each these indices will be given; definition, application, calculating formula, and its applied threshold limit values (TLVs) and effects experienced by workers.

\subsection{The Apparent temperature}

There are three main recognized types of apparent temperature: Heat index, Wind chill factor, and the wet-bulb globe temperature (WBGT). These three types correspond to three temperature ranges, as shown in Table-1.

Table 1: Temperature ranges and applied types of apparent temperature.

\begin{tabular}{|c|c|}
\hline $\begin{array}{c}\text { Temperature Celsius } \\
(\text { Fahrenheit })\end{array}$ & $\begin{array}{c}\text { The applied apparent } \\
\text { temperature type }\end{array}$ \\
\hline less $50 \mathrm{~F}\left(10^{\circ} \mathrm{C}\right.$ Celsius $)$ & The wind chill is applied \\
\hline $\begin{array}{c}\text { Between } 51-80 \mathrm{~F} \\
\left(10-26.7^{\circ} \mathrm{C}\right),\end{array}$ & The ambient air temp. is applied \\
\hline Above $80 \mathrm{~F}\left(26.7^{\circ} \mathrm{C}\right)$, & $\begin{array}{c}\text { The comfort heat index is } \\
\text { applied }\end{array}$ \\
\hline
\end{tabular}

\subsection{The comfort heat index}

The heat index is an indicator for calculating the dangers and to avoid Heat illnesses in working environment, resulted from combined effect of air ambient environment temperature, relative humidity and exposure (stress and clothing), and initiating heat alert procedures.

When applied: The heat index is applied, only when three condition are met: $a$ ) temperatures $\left.>26.7^{\circ} \mathrm{C} \mathrm{s}(80 \mathrm{~F}), b\right)$ the relative humidity is $\geq 40 \%$ and) the dew point temperature is $\geq 54^{\circ} \mathrm{F}\left(12^{\circ} \mathrm{C}\right)$.

Calculating Heat Index: Expression given by Eq. (1) can be applied for calculating the heat index. Where: F: temperature in degrees Fahrenheit, the HI index is calculated based on temperatures in the shade. $\mathrm{H}$ : relative humidity in decimal (divide the relative humidity by 100)[14].

$\mathrm{HI}=-42.379+2.04901523 * \mathrm{~F}+10.14333127 * \mathrm{H}-0.22475541$

$* \mathrm{~F}^{*} \mathrm{H}-6.83783 * 10^{-3} * \mathrm{~F}^{2}-5.481717 * 10^{-2} * \mathrm{H}^{2}+1.22874 * 10$

$3 * \mathrm{~F}^{2} * \mathrm{H}+8.5282 * 10^{-4} * \mathrm{~F}^{*} \mathrm{H}^{2}-1.99 * 10^{-6} * \mathrm{~F}^{2} * \mathrm{H}^{2}$

the applied threshold limit values (TLVs) for the heat (HI) index and experienced by workers and disorders are shown in Table-2 
International Journal of Engineering Research and Technology. ISSN 0974-3154, Volume 13, Number 5 (2020), pp. $984-994$

C International Research Publication House. https://dx.doi.org/10.37624/IJERT/13.5.2020.984-994

Table 2: Examples on applied TLVs and effects of the heat index (shaded values) experienced by workers

\begin{tabular}{|l|l|l|}
\hline $\begin{array}{l}\text { Temperature } \\
\text { Celsius } \\
(\text { Fahrenheit })\end{array}$ & $\begin{array}{l}\text { Zone } \\
\text { color }\end{array}$ & $\begin{array}{l}\text { Disorders of the heat index } \\
\text { experienced by workers }\end{array}$ \\
\hline $\begin{array}{l}\text { Less than } 27^{\circ} \mathrm{C} \\
\left(80^{\circ} \mathrm{F}\right)\end{array}$ & Yellow & $\begin{array}{l}\text { Caution: potential of fatigue with } \\
\text { prolonged exposure }\end{array}$ \\
\hline $\begin{array}{l}27-32^{\circ} \mathrm{C} \\
\left(80-90^{\circ} \mathrm{F}\right)\end{array}$ & Pink & $\begin{array}{l}\text { Extreme caution: prolonged } \\
\text { exposure and/or physical activity } \\
\text { may cause heat cramps and heat } \\
\text { exhaustion }\end{array}$ \\
\hline $\begin{array}{l}32-41^{\circ} \mathrm{C} \\
\left(90-105^{\circ} \mathrm{F}\right)\end{array}$ & $\begin{array}{l}\text { Danger: prolonged exposure } \\
\text { and/or physical activity may lead } \\
\text { to muscle } \\
\text { cramps and heat exhaustion are } \\
\text { probable }\end{array}$ \\
\hline $\begin{array}{l}41-54^{\circ} \mathrm{C} \\
\left(105-130^{\circ} \mathrm{F}\right)\end{array}$ & Orangestroke; \\
\hline $\begin{array}{l}\text { Over } 54^{\circ} \mathrm{C} \\
\left(\text { over } 130^{\circ} \mathrm{F}\right)\end{array}$ & Red & $\begin{array}{l}\text { Extreme danger: continued } \\
\text { exposure may lead to heat stroke } \\
\text { or sunstroke }\end{array}$ \\
\hline
\end{tabular}

\subsubsection{Dew Point temperature versus Humidity}

The effects of how comfortable it will feel-like (The experienced comfortable level) in terms of dew point temperature, humidity increases relatively with the increase of dew point temperature.

The general experienced comfortable levels in terms of the dew point temperature are shown in Table-3.

Calculating the dew point temperature: Simple expression that gives an approximation value is given by Eq.(2). It is applied when relative humidity values are above $50 \%$ [15].

$$
\mathrm{DP}=\mathrm{T}-((100-\mathrm{H}) / 5 .)
$$

Where: $\mathrm{H}$ is percent of relative humidity, and $\mathrm{T}$ : the ambient temperature $\mathrm{C}$.

Table 3: The general experienced comfortable level in terms of the dew point temperature

\begin{tabular}{|c|c|c|}
\hline \multicolumn{2}{|c|}{ The dew point temp } & \multirow{2}{*}{ Experienced Comfortable } \\
\hline Fahrenheit & Celsius & \\
\hline $\mathrm{DP}<=55$ & $\mathrm{DP}<=12.8$ & Dry and comfortable \\
\hline $\begin{array}{l}\text { DP between } \\
55-65\end{array}$ & $\begin{array}{c}\text { DP between } \\
12.8-18.3\end{array}$ & $\begin{array}{l}\text { Becoming sticky with } \\
\text { muggy evenings }\end{array}$ \\
\hline $\mathrm{DP}>=65$ & $\mathrm{DP}>=18.3$ & $\begin{array}{l}\text { Lots of moisture in the air, } \\
\text { becoming oppressive }\end{array}$ \\
\hline
\end{tabular}

\subsubsection{The Wind chill factor}

The wind chill factor is a measure used to describe how the ambient temperature feels like to human's body, because of the passing flow of lower temperature wind, at given wind speed and resulting experienced comfort or dangers on workers. Using other words, it tells us how cold the wind is.

Application of the wind chill factor: The chill factor is applied, to measure apparent temperature, only in two conditions: $a$ )the ambient air temperature is equal to or less than $\left.50^{\circ} \mathrm{F}\left(10^{\circ} \mathrm{C}\right), b\right)$ Ambient wind speed is five miles/hour or greater[16]. The indicator is applied, based on wind speed, wind temperature (when it is less than $50^{\circ} \mathrm{F}\left(10^{\circ} \mathrm{C}\right)$ ), and exposure time, for predicting the dangers on workers (like frostbite or hypothermia), from winter winds and freezing temperatures.

Calculating chill factor: The expressions for calculating chill factor in terms of two values: of the ambient air temperature and its speed is given by Eqs. (3)(4). Where, in Eq. (3) air temperature is measured in degrees Fahrenheit and wind speed is measured in meter per hours. Meanwhile, for Eq. (4) air temperature is measured is in degrees Celsius $\left({ }^{\circ} \mathrm{C}\right)$ and wind speed is measured in kilometer per hours.

Wind speed, for calculating the Wind chill factor, is measured at ten meters height, in case wind speed is measured on other level e.g. ground level, then it is required to multiply the resulted value by a factor. For ground level measurement multiply the resulted value by 1.5 to get, the value of speed at ten meters height.

Wind chill factor

$$
=35.75+0.6215 * \mathrm{~T}-35.75 * \mathrm{~V}^{0.16}+0.4275 * \mathrm{~T} * \mathrm{~V}^{0.16}
$$

Wind chill factor

$$
=13.74+0.6215 * \mathrm{~T}-11.75 * \mathrm{~V}^{0.16}+0.3965 * \mathrm{~T} * \mathrm{~V}^{0.16}
$$

The applied threshold limit values (TLVs) for use in the workplace and experienced effects are shown in Table- 4.

Table 4: The applied Wind chill factor TLVs and effects experienced by workers.

\begin{tabular}{|l|l|}
\hline $\begin{array}{l}\text { Temperature } \\
(\text { Fahrenheit })\end{array}$ & $\begin{array}{l}\text { Wind chill factor effects experienced by } \\
\text { workers }\end{array}$ \\
\hline Above +30 & Chilly. Generally unpleasant \\
\hline$(+15)-(+30)$ & Cold. Unpleasant. \\
\hline$(0)-(+15)$ & Very cold. Very unpleasant \\
\hline$(0)-(-20)$ & Bitter cold. Frostbite possible \\
\hline$(-20)-(-60)$ & Extremely cold. Frostbite expected \\
\hline Less -60 & Frigidly cold. flesh likely will freeze \\
\hline
\end{tabular}




\subsection{The wet-bulb globe temperature (WBGT)}

It is a key factor in evaluating many work environment states, situations and conditions. Its value can seriously affect the health of workers and reduce tolerance to other environmental hazards; therefore, WBGT index has many applications; examples include, in hot industrial environment and under given environment factors, applied to calculate the proper exposure levels, using this value as a guide in adjusting physical exertion under these conditions and predict the resulting effects, to indicate the heat category for water intake and physical activity level.

Color code is used, based on the WBGT value. The applied threshold limit values (TLVs) for use in the workplace and Intensity of physical exertion is listed in Table -5 .

Table-5: The applied WBGT TLVs and Intensity of physical exertion

\begin{tabular}{|l|l|l|l|}
\hline $\begin{array}{l}\text { WBGT } \\
\left({ }^{\circ} \mathbf{F}\right)\end{array}$ & $\begin{array}{l}\text { WBGT } \\
\left({ }^{\circ} \mathbf{C}\right)\end{array}$ & Color & $\begin{array}{l}\text { Intensity of Physical } \\
\text { Exercise }\end{array}$ \\
\hline$\leq 78-81.9$ & $\leq 25.6-$ & White & $\begin{array}{l}\text { Caution, extreme physical } \\
\text { exertion likely leads to heat } \\
\text { stroke or heat exhaustion }\end{array}$ \\
\hline $82-84.9$ & $\begin{array}{l}27.8- \\
29.4\end{array}$ & Green & $\begin{array}{l}\text { Heat stress likely happened } \\
\text { after 45 min of heavy } \\
\text { exertion }\end{array}$ \\
\hline $85-87.9$ & $\begin{array}{l}29.4- \\
31.0\end{array}$ & Yellow & $\begin{array}{l}\text { Heat stress likely happened } \\
\text { after 30 min of heavy } \\
\text { exertion }\end{array}$ \\
\hline $88-89.9$ & $31.1-$ & Red & $\begin{array}{l}\text { Body will be stressed after } \\
\text { 20 minutes. Strenuous } \\
\text { exercise is curtailed for all } \\
\text { personnel }\end{array}$ \\
\hline $\begin{array}{l}32.1 \\
\text { Above }\end{array}$ & $\geq 32.2$ & Black & $\begin{array}{l}\text { body will be stressed after 15 } \\
\text { minutes; Physical works are } \\
\text { suspended for all personnel }\end{array}$ \\
\hline
\end{tabular}

Calculating WBGT factor: To produce a final value of the WBGT factor (heat stress index), three measurements take place; dry bulb temperature, globe temperature and humidity (by measuring the wet bulb temperature). The WBGT factor is calculated for both indoor and outdoor applications.

For outdoor applications, the WBGT factor, is calculated by Eq. (5), while for indoor applications, the WBGT factor by Eq. (6) for indoor application, when solar radiation is negligible and $T_{G}=T_{D}$. the WBGT factor is calculated by Eq. (7).

$$
\begin{aligned}
& \mathrm{WBGT}=0.7 \mathrm{~T}_{\mathrm{W}}+0.2 \mathrm{~T}_{\mathrm{G}}+0.1 \mathrm{~T}_{\mathrm{D}} \\
& \mathrm{WBGT}=0.7 \mathrm{~T}_{\mathrm{W}}+0.3 \mathrm{~T}_{\mathrm{G}} \\
& \mathrm{WBGT}=0.7 \mathrm{~T}_{\mathrm{W}}+0.3 \mathrm{~T}_{\mathrm{D}}
\end{aligned}
$$

$\mathrm{T}_{\mathrm{G}}$ : Globe temperature, which indicates radiant heat.
$\mathrm{T}_{\mathrm{D}}$ : Dry bulb temperature, it is the actual ambient air temperature.

$\mathrm{T}_{\mathrm{W}}$ : The wet bulb temperature, which indicates humidity, can be measured by using a thermometer covered in water-soaked cloth (with the bulb wrapped in wet muslin) over which air is passed[17].The wet-bulb can be calculated based on two values: air temperature and Relative humidity, as by Eq.(8)

$\mathrm{Tw}=\mathrm{T} * \arctan \left[0.151977 *(\mathrm{H} \%+8.313659)^{0.5}\right]+\arctan (\mathrm{T}$ $+\mathrm{H} \%)-\arctan (\mathrm{H} \%-1.676331)+0.00391838 *(\mathrm{H} \%)^{1.5} *$ $\arctan (0.023101 * \mathrm{H} \%)-4.686035$

\subsection{Expressions for the apparent temperature}

Different expressions exist for calculating the apparent temperature as one value. One expression is given by Eq. (9). This equation form is modified form of the Steadman Apparent Temperature Equation. This form does not account for solar radiance.

$$
\mathrm{AT}=\mathrm{T}_{\mathrm{D}}+0.33 * \mathrm{P}-0.70 * \mathrm{~V}-4.00
$$

Where: $\mathrm{P}$ is the water vapor pressure $(\mathrm{hPa})$; calculated by Eq. (10)

$$
\mathrm{P}=\mathrm{H}^{*} 6.105 * \mathrm{e}^{(17.27 * \mathrm{Ta} /(237.7+\mathrm{Ta}))}
$$

\subsection{The Thermal comfort}

At room temperature, with range between 20 to $22{ }^{\circ} \mathrm{C}$ (68 to $72^{\circ} \mathrm{F}$ ), most people will feel comfortable. This comfortability condition differs greatly between different individuals[18].Thermal comfort is defined as: that state of mind which demonstrate satisfaction with the thermal location[1, 19]. Based on this definition, Comfort is a subjective sensation.

The key factors that affect thermal comfort which define heat gain and loss, also can be categorized as environmental and personal. Environmental factors involve thermal radiation, temperature, speed and humidity while personal factors such as clothing insulation and personal activity. Psychological factors, such as expectations, are also thermal comfort[20-23]

Relative temperature and humidity play a vital role on the thermal comfort, therefore, referring to NOAA's National Weather Service and the Heat Index[24] shown in Figure 1.The thermal comfort can be determined using the Heat Index. The meaning of the values the thermal comfort is defined as shown in Table-6.

Table 6: Relating the thermal comfort to the Heat Index

\begin{tabular}{|l|l|}
\hline $\begin{array}{l}\text { the Heat Index in } \\
\text { degrees Celsius }\end{array}$ & $\begin{array}{l}\text { The meaning of the values in } \\
\text { terms of the thermal comfort } \\
\text { experienced by workers }\end{array}$ \\
\hline$<30^{\circ} \mathrm{C}$ & No discomfort \\
\hline $30-40^{\circ} \mathrm{C}$ & Mild discomfort \\
\hline $40-45^{\circ} \mathrm{C}$ & High discomfort \\
\hline$>45^{\circ} \mathrm{C}$ & Risky \\
\hline$>54^{\circ} \mathrm{C}$ & Heat stroke anticipated \\
\hline
\end{tabular}




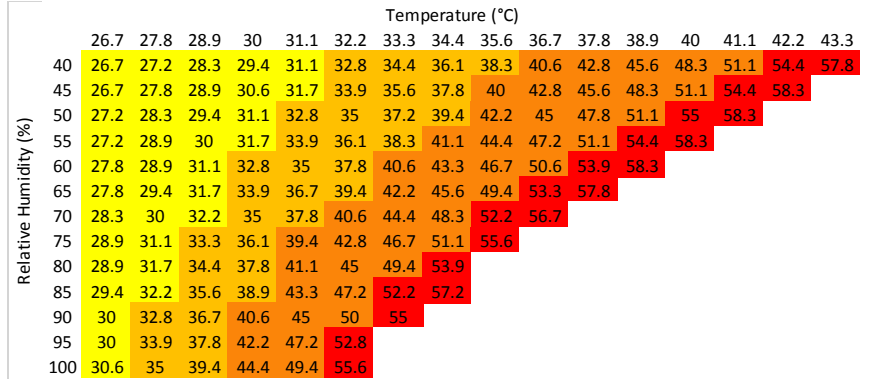

Figure 1: Heat Index in ${ }^{\circ} \mathrm{C}[24]$

\subsection{The Discomfort Index}

The thermal comfort/discomfort of people, was proposed by Thom[13], the expression form given by Eq.(11). This equation shows that the discomfort index values are almost the same as the WBGT index for indoor application, (when solar radiation is negligible and $\mathrm{T}_{\mathrm{G}}=\mathrm{T}_{\mathrm{d}}$ ), as given by Eq. (6). Another form for Thom's formula, for monthly range, is given by Eq. (12). Third expression for calculating discomfort index is given by Eq. (13). Where: T: mean monthly temperature in $\left({ }^{\circ} \mathrm{C}\right) . \quad \mathrm{H}$ : mean monthly relative humidity of air (\%).

$\mathrm{DI}=0.5 * \mathrm{~T}_{\mathrm{W}}+0.5 * \mathrm{~T}_{\mathrm{d}}$

$\mathrm{DI}=\mathrm{T}-(0.55-0.0055 \mathrm{H})(\mathrm{T}-14.5)$

$D I=0.4\left(T_{d}+T_{W}\right)+15$

Application of the discomfort index: The higher the value of the discomfort index, the higher the value of discomfort. A criterion was developed, based on the discomfort index to describe the environmental heat stress and correlate thermal sensation, this criterion is listed in Table-7. Also study conducted on 108 participants showed that DI is highly correlated with WBGT[1] this is also is shown in Figure 2.

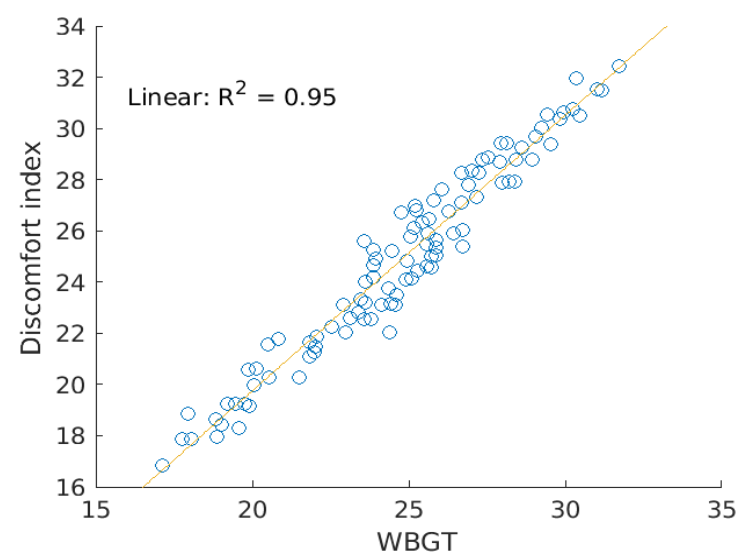

Figure 2: Correlation between WBGT and DI [1]

\subsubsection{The temperature-humidity index, (THI)}

It is the modified form of the discomfort index that utilizes the heat stress. It is a useful and easy measure to evaluate the risk degree (level) of thermal stress experienced by workers in a given environment. It measures the integrated effect of environmental temperature and relative humidity. The THI in degree Celsius ${ }^{\circ} \mathrm{C}$, can calculated as given by Eq. (14).

$$
\mathrm{THI}=\mathrm{T}_{\mathrm{d}}-0.55[1-(\mathrm{RH} / 100)]\left(\mathrm{T}_{\mathrm{d}}-14.44\right)
$$

The levels of risks corresponding to given heat stress were classified according to the THI values and are reported in[25, 26] as listed in Table- 8 .

Table 7: Characterizing the environmental heat stress and correlate thermal sensation $[27,28]$

\begin{tabular}{|l|l|}
\hline $\begin{array}{l}\text { DI value } \\
\left({ }^{\circ} \mathbf{C}\right)\end{array}$ & $\begin{array}{l}\text { Discomfort levels and the heat } \\
\text { load experienced by workers }\end{array}$ \\
\hline Below 22 & No discomfort: No heat stress \\
\hline $\begin{array}{l}\text { Between } \\
22-24\end{array}$ & Mild discomfort: minor sensation of heat \\
\hline $\begin{array}{l}\text { between } \\
24-28\end{array}$ & $\begin{array}{l}\text { Moderately discomfort: individuals feel very } \\
\text { hot, and the heat load is relatively heavy, it is } \\
\text { likely difficult to perform physical work }\end{array}$ \\
\hline $\begin{array}{l}\text { between } \\
28-32\end{array}$ & $\begin{array}{l}\text { Severe discomfort: Severe heat load. Risk } \\
\text { increase with physical work }\end{array}$ \\
\hline Above 32 & It is a state of medical emergency \\
\hline
\end{tabular}

Table-8: Levels of risks related to heat stress

\begin{tabular}{|c|c|}
\hline $\begin{array}{l}\text { THI } \\
\text { value } \\
\left({ }^{\circ} \mathrm{C}\right)\end{array}$ & $\begin{array}{l}\text { The risk degrees (levels) of thermal stress } \\
\text { experienced by workers }\end{array}$ \\
\hline Less 27 & Safe, no risks \\
\hline $\begin{array}{l}\text { Between } \\
27-32\end{array}$ & $\begin{array}{l}\text { Potential of heat fatigue with prolonged } \\
\text { activity and exposure }\end{array}$ \\
\hline $\begin{array}{l}\text { Between } \\
32-41\end{array}$ & $\begin{array}{l}\text { Potential of Sunstroke and heat exhaustion } \\
\text { with prolonged activity and exposure }\end{array}$ \\
\hline $\begin{array}{l}\text { Between } \\
41-54\end{array}$ & Sunstroke and heat cramps are expected \\
\hline Above 54 & $\begin{array}{l}\text { Heat stroke and Sunstroke, or delirium are } \\
\text { highly expected }\end{array}$ \\
\hline
\end{tabular}

\section{SYSTEM CONFIGURATION, HARDWARE DESIGN, BUILDING AND INTEGRATION ISSUES}

As noted, the suggested design of the measuring tool consists of main four subsystems; sensors modules, main control unit with control algorithm, wireless communication, data displaying and notification subsystems Interfaces and power supplies. 


\subsection{The sensor modules hardware selection, building and design}

The sensor module is designed to be consisting of the next units: group of specific sensors, control unit, wireless communication unit, power supply unit. Each sensor is selected for reading each of the basic environmental variables and factors in a given industrial environment, mainly; ambient Temperature, Humidity, air flow (wind speed), solar radiation and exposure (stress and clothing).

Different options are available, for measuring both temperature and humidity in industrial locations. Suitable sensor choice could be Digital Sensor SHT3x (RH/T), shown in Figure 3(a). Another choice is hyt939 industrial grade humidity and temperature sensor shown in Figure 3(b). A third option is shown in Figure 3(c) Grove Temperature and Humidity Sensor. As a backup sensor for measuring only the temperature is shown in Figure 3(d) Temperature waterproof DS18B20 sensor. A suitable sensor choice for air flow measuring in industrial space are two types of Wind Sensor Rev. P and V, Wind Sensor Rev. P is shown in Figure 3(e).

Solar radiation levels in a given space can be difficult to measure. Solar irradiance can be simply, defined as the power per unit area received from the Sun. Using this definition, a simple way is introduced to give approximate measurements of solar radiation, by calculating power from the solar cell and dividing by its area. The circuit set up is as shown in Figure 4, the circuit consists of a solar cell, with area $\left(A=a^{*} b\right)$. Maximum Voltage output of selected solar cell (assuming for selected cell is 5VDC). The cell's red wine is connected through resistor (with resistance value that is many times greater than the internal resistance of the cell, e.g. 10k ohm)

The power is calculated as follows: The electric power is given by $\left(\mathrm{P}=\mathrm{I}^{*} \mathrm{~V}\right)$, Ohm's law $\left(\mathrm{V}=\mathrm{I}^{*} \mathrm{R}\right)$, we have power to be as by Eq. (15), solar irradiance is calculated by Eq. (16).

$$
\begin{gathered}
\mathrm{P}=\mathrm{I} * \mathrm{~V}=(\mathrm{V} / \mathrm{R}) * \mathrm{~V}=\mathrm{V}^{2} / \mathrm{R} \\
\text { Solar radiation = power } / \text { area }
\end{gathered}
$$

In each sensor module, short range wireless communication is utilized to wirelessly interface Sensor module to main control unit. Two options available'; radio transceivers or WIFI communications, a suitable option for industrial applications and proof of concept are the NRF24L01 module shown in figure 5(a) and the ESP8266 Wi-Fi module shown in figure 5(b). A good option for control unit is based on the ATmega328P microcontroller Arduino Nano board shown in Figure 6. A suitable choice for power supply is $3.6 \mathrm{~V} 2100$ mAh VTC4 rechargeable lithium acid battery shown in Figure 7. The suggested design of sensor module is expressed in terms of pictorial diagram interconnections between components are shown in Figure 8.

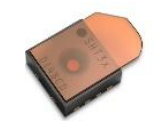

Figure 3(a): Digital Sensor SHT3x (humidity and temperature)

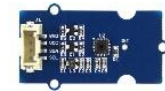

Figure 3(c): Grove

Temperature and Humidity Sensor

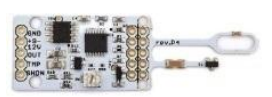

Figure 3(e): Wind Sensor Rev. P

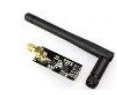

Figure 5(a): the NRF24L01 module

Figure 6: Arduino Nano board
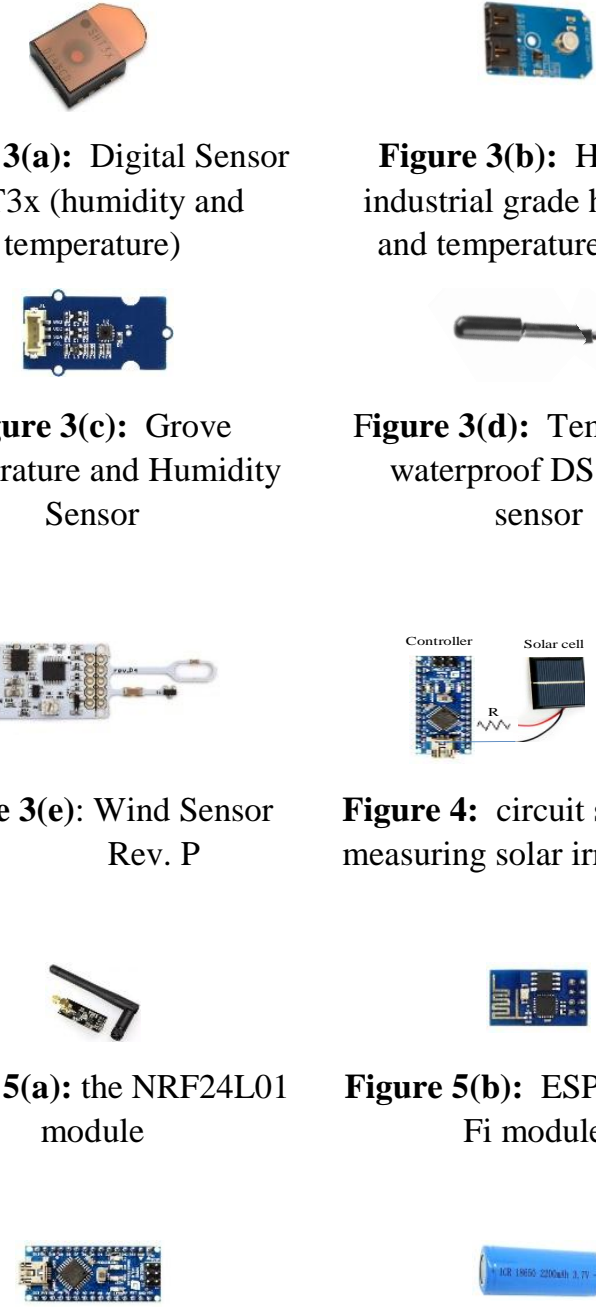

Figure 3(b): HYT939 industrial grade humidity and temperature sensor

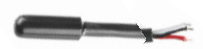

Figure 3(d): Temperature waterproof DS18B20 sensor

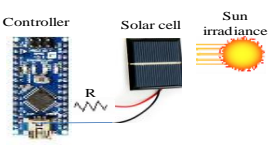

Figure 4: circuit set up for measuring solar irradiance

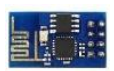

Figure 5(b): ESP8266 WiFi module,

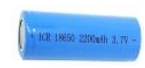

Figure 7: $3.6 \mathrm{~V} \mathrm{2100mAh}$ VTC4 rechargeable lithium acid battery

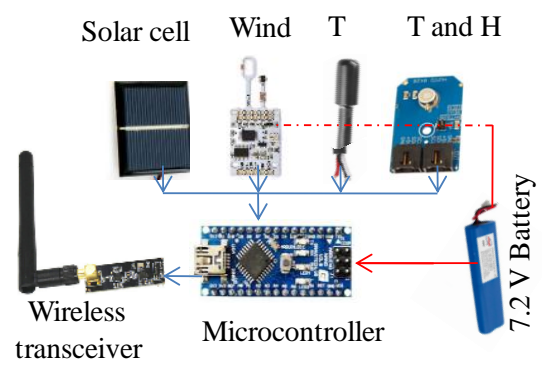

Figure 8: The pictorial diagram representing the suggested design of sensor module

\subsection{The main control unit module; hardware design selection, and building}

The main control unit tasks are to receive readings from each and all sensor modules, process these data and calculate all industrial indices. The main control unit module consists of the next units: microcontroller as physical controller, wireless 
communication unit, power supply unit and interface /HMI modules for data displaying and alarms.

Different options available for physical microcontroller-based control unit, to be the core of the main control unit. A suitable choice for the present design is using Atmel SAM3X8E ARM Cortex-M3 CPU Arduino Due board shown in Figure 9.

The main control unit is designed to be both, portable and fixed at a specific location. When portable, a pair of rechargeable lithium acid $(7.2 \mathrm{~V})$ batteries is utilized as a suitable power source. When fixed required, to use the main control unit at fix location. AC source with AC to DC adapter can be utilized to power the unit. The system is designed with Lithium Battery Charger for charging the two batteries.

In case the main control unit is needed to be placed on a fix location, for power supplying, an AC to DC power converter, shown in figure 10 can be utilized. Meanwhile, in case the main control unit is required to be portable as shown in Figure 6, the 3.6V 2100mAh VTC4 rechargeable lithium acid battery, is a suitable choice as power supply.

The diagram presented in Figure 11 shows the suggested design for main control unit module, expressed pictorially with interconnections between components.

\subsubsection{System's working principle algorithms and representation}

The working principle represented using flowchart is shown in Figure 12(a). The system design represented using block diagrams are shown in Figure 12(b)(c)(d). Where; in Figure 12(b), is shown the wireless sensor unit, in Figure 12(c), is shown the Base station unit and finally in Figure 12(d), is shown the data displaying unit.

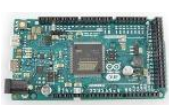

Figure 9: control unit for base station (Arduino Due board)

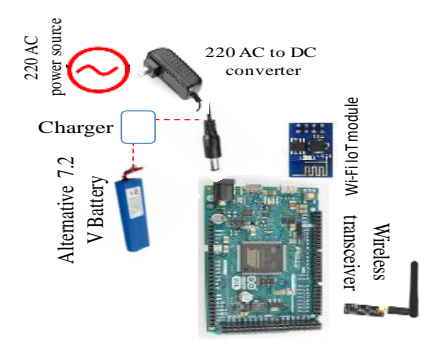

Figure 11: The pictorial diagram of main control unit module design

Figure 10: $220 \mathrm{AC}$ to 9

DC power converter

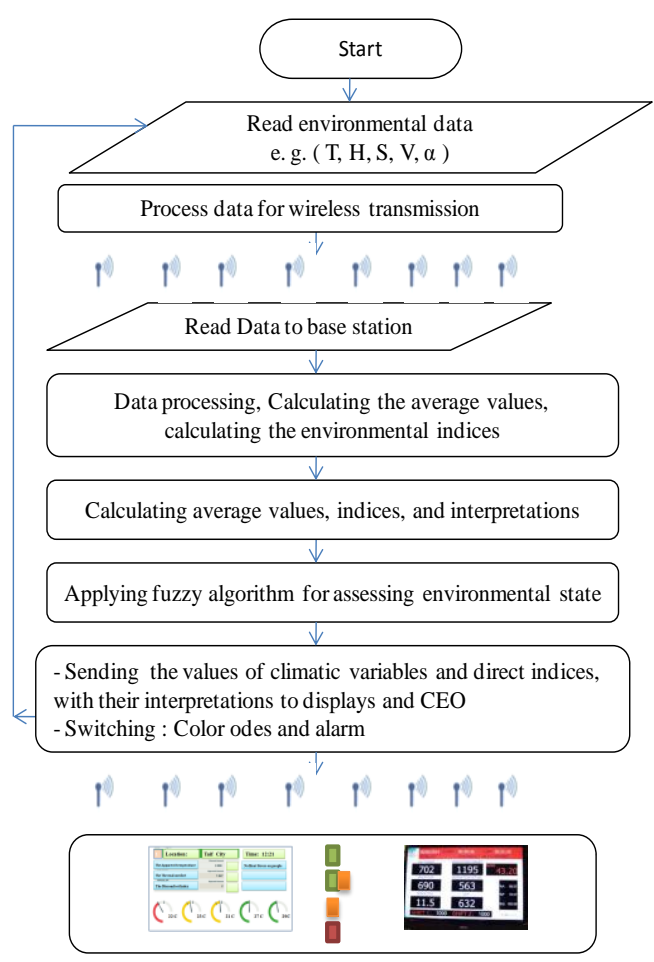

Figure 12(a): The working principle algorithm representation

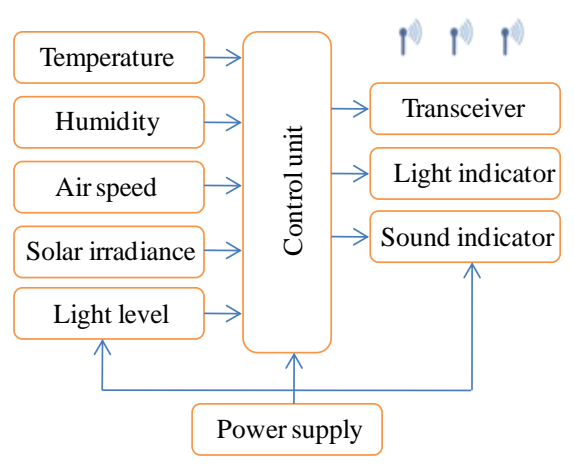

Figure 12(b): Wireless sensor module

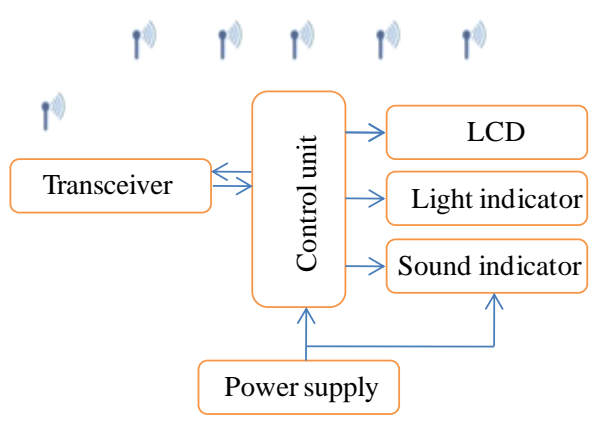

Figure 12(c): Base station module 


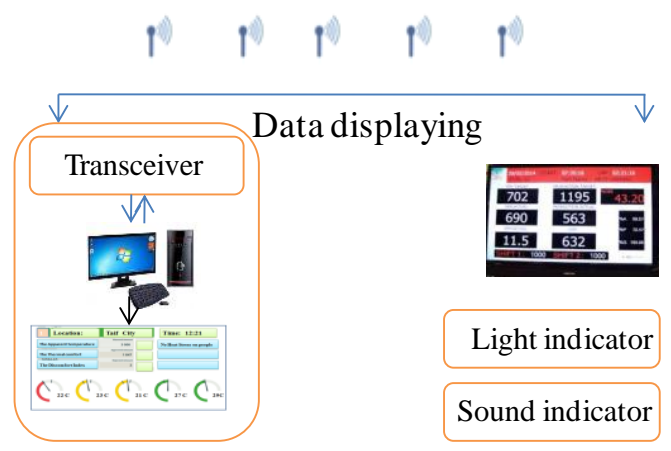

Figure 12(d): Data displaying units

Figure 12(b, c, d): The suggested system design represented using block diagram

\subsubsection{Fuzzy algorithm design}

Fuzzy algorithm was designed to assess the overall environmental state conditions, the inputs to the algorithm are the five environmental indices. The output is one single value that represents the assessment of working condition state. Each input membership function is developed around one environmental index like the comfort heat index and WBGT, with universe of discourse and ranges corresponding to index's limits and values in the related table. Linguistic variables for each index were derived using the interpretations in the listed above, 1-7 tables.

The fuzzy algorithm is designed and built in MATLAB/Simulink environment. The built-in fuzzy algorithm with input and output membership functions, Simulink model are shown in Figure $13(\mathrm{a}, \mathrm{b}, \mathrm{c})$. The knowledge rules base and inference mechanism that reflects the collaborative effect of all environmental indices to result in one of four working conditions states: (1) Comfortable working condition, (2) Acceptable working condition with some experienced disorders, (3) Working condition with severe discomfort, (4) Extreme dangerous conditions for work. Table 9 shows these four working condition states, their limits and values.

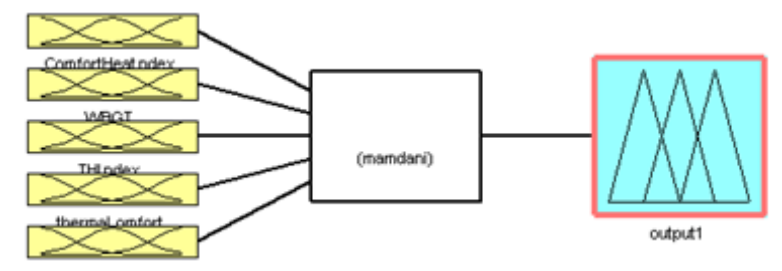

Figure 13(a): The fuzzy algorithm design in MATLAB/Simulink.
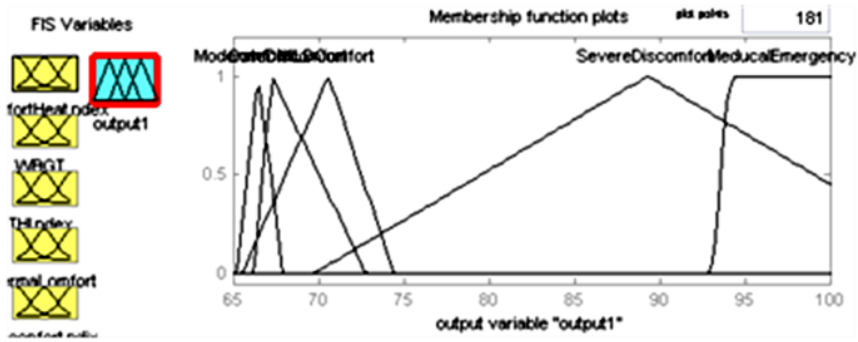

Figure 13(b): The output membership functions,

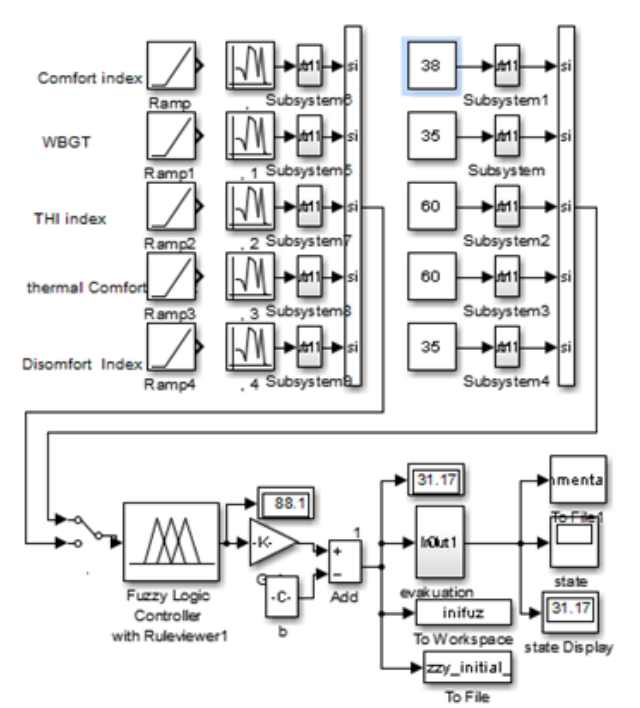

Figure 13(c): The developed Simulink model for testing fuzzy algorithm

Table 9: The four working condition states, their limits and values

\begin{tabular}{|c|c|c|}
\hline \begin{tabular}{|c|}
$\begin{array}{c}\text { Output value } \\
\left(\text { Temperature }^{0} \mathrm{C}\right)\end{array}$ \\
\end{tabular} & Working condition & Color \\
\hline Less 24 & Comfortable & Green \\
\hline Between $24-30$ & $\begin{array}{l}\text { Acceptable, with some } \\
\text { disorders }\end{array}$ & $\begin{array}{l}\text { Green and } \\
\text { Brown }\end{array}$ \\
\hline Between 30-32 & Severe Discomfort & Brown \\
\hline Bigger than32 & Extreme dangerous & Red \\
\hline
\end{tabular}

\subsubsection{Fuzzy algorithm Testing and evaluation}

Testing the developed fuzzy algorithm was done using the threshold limits explained in tables 1 to 7 with their corresponding interpretations. Each time the model was run; different values were assigned to each environmental index, such that these values are around one working condition state. The used input indices' values and testing result in terms of numerical, Linguistic and color values and are listed in table 9. 
The developed algorithm was also tested, when all the inputs are changing with increasing values. The ramp Simulink block with different slope values was used, representing different increase in input values of all indices with different increase rates. Figure 14(a) shows the evaluation results in response to inputting different combinations of indices' values. This curve shows the change in the assessment results depending on the increase in the indices' input values.

Figure 14(b) shows the evaluation results in response to inputting different initial high values of all indices. This curve shows the corresponding high results values of the how it feels like, in response to high indices' input values.

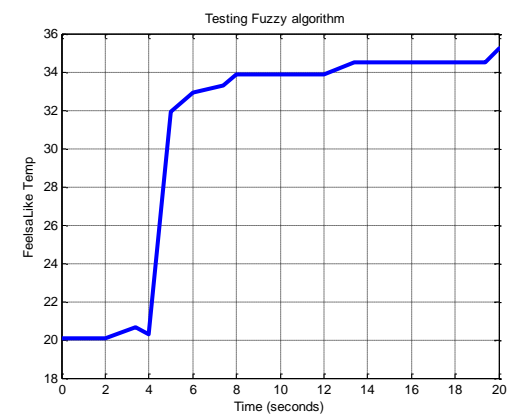

Figure 14(a): The evaluation results in response to inputting initial indices' values with different increasing slope values

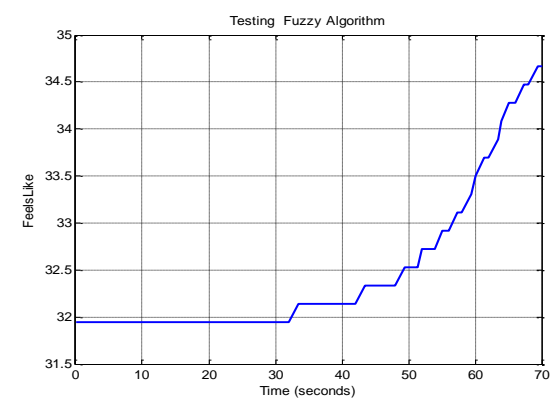

Figure 14(b): The evaluation results in response to inputting different combinations indices' values

\subsection{Interface and HMI modules; hardware design selection, and building}

In the suggested system design, interfaces are to be between: a) the main control unit, actuators and power supplies, $b$ ) the wireless communication between the two control units, $c$ ) the human machine interfaces (HMI) between the design and the users (e.g. supervisor, workers) for data inputting and reading.

Interfaces for driving the actuators (e.g. ON/OFF) including ventilations, fans, lights and sounds alarms, a suitable choice for continuous behavior control MOSFET based driver a good example for controlling AC load is two MOSFETs in series, with their source pins connected together (Figure 15(a, b)) and for ON/OFF operation is the solid state relays or relays with driver (Figure 15(c, d)).
For wireless communication between main control unit, sensors display and alarms, the applied for sensors module wireless communication shown in figure $4 \mathrm{up}$, is a suitable choice.

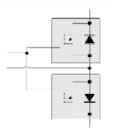

Figure 15(a): Two MOSFETs in series, with their source pins connected together

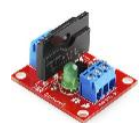

Figure 15(c):

Sparkfun Solid State

Relay Board

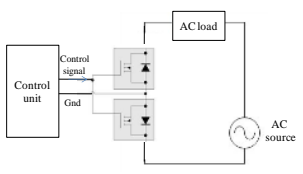

Figure 15(b): Circuit design for utilizing MOSFET as drive to control AC loads

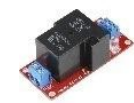

Figure 15(d): The Sparkfun relay board with driver

\subsubsection{HMI modules design: hardware selection, and building issues}

The human machine interfaces (HMI) between the system and users (e.g. workers, supervisors and enterprise's CEO) for notifications, data inputting and reading, can have different forms, including: displaying measured data using large displays (placed in elevated locations in industrial workshop) with sound and light alarm, example one such displays is the Overall Equipment Effectiveness (OEE) shown in Figure 16(a). These displays can be designed to display the following data; the value of the environmental index, its interpretation shortly described, experienced effect and recommendations.

Another HMI for data broadcasting and displaying is recommended for decision makers like supervisors and enterprise's CEOs. This display can be designed to represent and display data in different forms, including using a specially designed graphical user interface (GUI) that shows the readings of all environmental variables and indices, their limits, interpretations and recommendations. In case the CEO is located in far location e.g. far away from industrial plant, IoT can be applied to transmit data using ESP8266 Wi-Fi module, as shown in Figure 5(b). A suggested design for such application is shown in Figure 16(b).

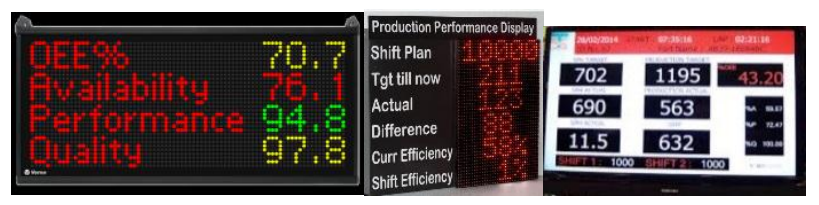

Figure 16(a): Overall Equipment Effectiveness (OEE) display examples that can be utilized 


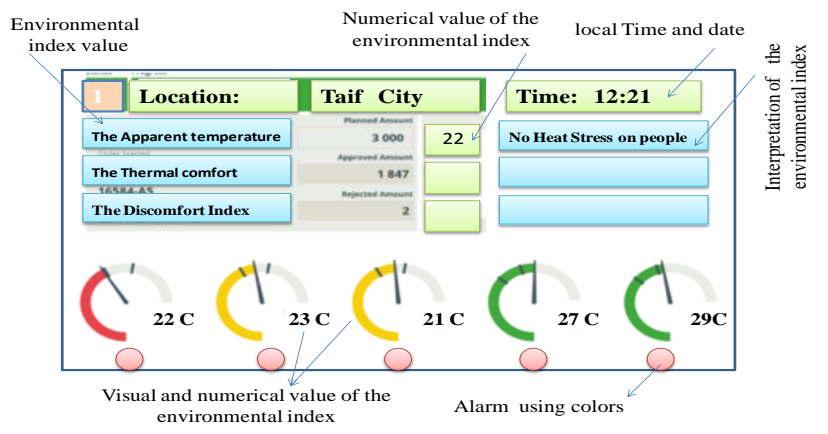

Figure 16(b): A design example on GUI as HMI for enterprises CEOs

\section{CALIBRATION AND TOOL' MEASUREMENT ACCURACY}

To reduce the error in final measurement and calculation values, to minimum possible values, to ensure that measuring tool is expressing actual values of all basic environmental variables and climate indices, calibration is applied, the linear least squares fitting technique is applied. It is assumed that the relation between the standard values measured using the standard equipment and the values obtained by the suggested measuring tool design is linear and can be expressed by a simple linear equation as $\mathrm{y}=\mathrm{ax}+\mathrm{b}$. Where $\mathrm{x}$ is the value from the suggested measuring tool design and $y$ is the value measured by using the standard devices for measuring e.g. WBGT, dew point and thermal comfort.

\section{CONCLUSIONS}

In this work a dependable design of real-time low-cost tool is introduced, for measuring and assessing industrial working environment climatic indices. A reliable hardware component including, circuits Interface and power supplies at low cost. Also, its industrial zones were selected and integrated in overall tool design. Fuzzy algorithm was built and tested to assess the surrounding working environment state. Human easy and low-cost interface was designed such as displays and GUI, for both workers and supervisors. In big and global enterprises, it is recommended to link all systems and work environment. Future work may concentrate how to link these big firms and corporation with the business intelligence system BI with help of internet of things IoT.

\section{REFERENCES}

1. Epstein, Y. and D.S. Moran, Thermal comfort and the heat stress indices. Industrial health, 2006. 44(3): p. 388-398.

2. Burgstall, A., et al., Heat warnings in Switzerland: Reassessing the choice of the current heat stress index. International journal of environmental research and public health, 2019. 16(15): p. 2684.

3. Morabito, M., et al., An Occupational Heat-Health Warning System for Europe: The HEAT-SHIELD
Platform. International journal of environmental research and public health, 2019. 16(16): p. 2890.

4. Liang, C., et al., A new environmental heat stress index for indoor hot and humid environments based on Cox regression. Building and Environment, 2011. 46(12): p. 2472-2479.

5. Steadman, R.G., A universal scale of apparent temperature. Journal of Climate and Applied Meteorology, 1984. 23(12): p. 1674-1687.

6. Radich, R., et al., Determining a realfeel seasonal index. 2019, Google Patents.

7. Steadman, R.G., The assessment of sultriness. Part I: A temperature-humidity index based on human physiology and clothing science. Journal of applied meteorology, 1979. 18(7): p. 861-873.

8. Steadman, R.G., The assessment of sultriness. Part II: effects of wind, extra radiation and barometric pressure on apparent temperature. Journal of Applied Meteorology, 1979. 18(7): p. 874-885.

9. Budd, G.M., Wet-bulb globe temperature (WBGT)—its history and its limitations. Journal of Science and Medicine in Sport, 2008. 11(1): p. 20-32.

10. Yaglou, C. and D. Minaed, Control of heat casualties at military training centers. Arch. Indust. Health, 1957. 16(4): p. 302-16.

11. Handbook-Fundamentals, A., Physiological principles and thermal comfort. ASHRAE, Atlanta, 1993.

12. Song, G. and F. Wang, Firefighters' Clothing and Equipment: Performance, Protection, and Comfort. 2018: CRC Press.

13. Thom, E.C., The discomfort index. Weatherwise, 1959. 12(2): p. 57-61.

14. Rothfusz, L.P. and N.S.R. Headquarters, The heat index equation (or, more than you ever wanted to know about heat index). Fort Worth, Texas: National Oceanic and Atmospheric Administration, National Weather Service, Office of Meteorology, 1990. 9023.

15. Lawrence, M., The relationship between relative humidity and the dewpoint temperature in moist air: A simple conversion and applications, B. Am. Meteorol. Soc., 86, 225-233. 2005, BAMS-86-2-225.

16. Anderson, G.B., M.L. Bell, and R.D. Peng, Methods to calculate the heat index as an exposure metric in environmental health research. Environmental health perspectives, 2013. 121(10): p. 1111-1119.

17. Gupton, G.W., HVAC Controls: Operation \& Maintenance. 2002: The Fairmont Press, Inc.

18. Ammer, C., The American Heritage Dictionary of Idioms: American English Idiomatic Expressions \& Phrases. 2013: HMH.

19. Fanger, P., Moderate thermal environments determination of the PMV and PPD indices and 
specification of the conditions for thermal comfort. ISO 7730, 1984.

20. De Dear, R. and G.S. Brager, Developing an adaptive model of thermal comfort and preference. 1998.

21. Olesen, B.W. and K. Parsons, Introduction to thermal comfort standards and to the proposed new version of EN ISO 7730. Energy and buildings, 2002. 34(6): p. 537-548.

22. Kim, J., et al., Field study of air conditioning and thermal comfort in residential buildings. 2016.

23. Chase, B., et al., A study of computer-based task performance under thermal stress. International Journal of Occupational Safety and Ergonomics, 2003. 9(1): p. 5-15.

24. NOAA's. NOAA's National Weather Service Heat Index 2020 [cited 202028 Mar 2020]; Available from: https://www.osha.gov/SLTC/heatillness/heat_index/noaa heatindex.html.

25. Hunter, C.H. and C.O. Minyard. Estimating wet bulb globe temperature using standard meteorological measurements. in Preprints Second Symp. Env. Appl., Long Beach, CA. 1999. Citeseer.

26. Abdel-Ghany, A., I. Al-Helal, and M. Shady, Human thermal comfort and heat stress in an outdoor urban arid environment: a case study. Advances in Meteorology, 2013. 2013.

27. Shapiro, Y. and D. Seidman, Field and clinical observations of exertional heat stroke patients. Medicine and science in sports and exercise, 1990. 22(1): p. 6-14.

28. Yousif, T.A. and H.M. Tahir, Application of Thom's thermal discomfort index in Khartoum state, Sudan. Journal of Forest Products and Industries, 2013. 2(5): p. 36.

Table 9: The testing results of developed Simulink module with fuzzy algorithm

\begin{tabular}{|c|c|c|c|c|c|c|c|c|}
\hline \multirow[b]{2}{*}{ Test \# } & \multirow{2}{*}{$\begin{array}{l}\text { Comfort } \\
\text { indix }\end{array}$} & \multirow{2}{*}{$\begin{array}{l}\text { WBGT } \\
\text { indix }\end{array}$} & \multirow{2}{*}{$\begin{array}{l}\text { THI } \\
\text { indix }\end{array}$} & \multirow[b]{2}{*}{ Thermal comfort } & \multirow[b]{2}{*}{ Discomfort index } & \multicolumn{3}{|c|}{ Enviromental state Assesment } \\
\hline & & & & & & $\begin{array}{l}\text { Numerical } \\
\text { value }\end{array}$ & $\begin{array}{l}\text { Liguistic } \\
\text { value }\end{array}$ & $\begin{array}{l}\text { Color } \\
\text { code }\end{array}$ \\
\hline 1) & 20 & 23 & 25 & 26 & 20 & 20.08 & Comfortable & Green \\
\hline 2) & 29 & 28 & 30 & 33 & 23 & $22 . .7$ & Comfortable & Green \\
\hline 3) & 35 & 30 & 38 & 42 & 26 & 29.4 & $\begin{array}{l}\text { Acceptable, / some } \\
\text { disorders }\end{array}$ & $\begin{array}{l}\text { Green and } \\
\text { Brown }\end{array}$ \\
\hline 4) & 60 & 35 & 60 & 47 & 34 & 31.95 & severe Discomfort & Brown \\
\hline
\end{tabular}

